\title{
General Ecology and Habitat Selectivity of Fresh Water Fishes of the Rawan Oya, Kandy, Sri Lanka
}

\section{Ravindra Jayaratne $^{1}$ and Thilina Surasinghe ${ }^{2}$}

\author{
${ }^{1}$ Department of Biological Sciences, Rajarata University, Mihintale, \\ Sri Lanka
}

${ }^{2}$ Department of Biological Sciences, Clemson University, USA, tsurasi@clemson.edu

\begin{abstract}
This study was conducted over a five-month period at Rawan Oya, a $13.5 \mathrm{~km}$ long left bank tributary of the River Mahaweli. Data on species composition and mircohabitat conditions were collected from 30 random sampling sites, representing 10 pools, 10 riffles and 10 runs. A single observation was made at each site, where a $10 \mathrm{~m}$-length of the stream was blocked with drag nets to get the values for abundance. Fishes were captured using the cast nets and scoop nets, identified and released back at the site of capture. The species richness, relative abundance and the microhabitat conditions were recorded for each habitat type. Physico-chemical parameters of water such as the stream velocity, temperature, $\mathrm{pH}$, water depth, conductivity, Hardness, $\mathrm{DO}$ and $\mathrm{BOD}_{5}$ were determined monthly at pre-selected sampling sites. A questionnaire survey was done among people in adjacent villagers, who are selected randomly. A total of 15 fish species belonging to 8 families were recorded of which 2 are endemic and 4 are exotic. The subsequent data analysis revealed that the Shannon Wiener diversity index and the Magalef Index are significantly high in pools. ANOVA test showed significant variation among the 3 habitat types in terms of the microhabitat features measured. Further, the Pearson Correlation test demonstrated that the different fish species have different microhabitat preferences and different habitat associations. Runs seemed to be the most suitable habitats for most of the fish species lotic habitat with the highest species richness compared with the other two habitat types (12 species). Riffles harbored the poorest in species composition ( 2 species). Pools had an intermediate number of species (9). Puntius bimaculatus, Hypostomus sp and Tor khudree only occurred in pools while Devario malabaricus, Glossogobius giuris, Lepidocephalichthys thermalis, Mystus vittatus, Rasbora daniconius and Xiphophorus maculatus are confined to runs of the stream with no species confined to riffles. Garra ceylonensis and Schistura notostigma occupy all three kinds of habitat types but with higher abundances in riffles. Among the fish found only in pools and runs, Puntius filamentosus were recorded in significantly higher numbers in pools than that in runs in contrast to the alien species such as Poecilia reticulata and Oreochromis mossambicus that showed a higher preference for runs.
\end{abstract}

Key words: Stream Ecosystems, Freshwater Fish, Water Quality, Conservation, Montane Forests 


\section{Introduction}

Sri Lanka is an Indian Oceanic island $\left(65610 \mathrm{~km}^{2}\right)$ with distinct geographical zones, climatic regions and monsoon patterns (Aston and Gunathilleke, 1987). Attributed to the geo-climatic and hydrological diversification within a relatively small land area, the island is having a wide range of on terrestrial and aquatic ecosystems harboring an exceptionally rich biodiversity and high endemism (Gunathilleke and Gunathilleke, 1990; Myers et al., 2000). The country has a variety of lentic and lotic freshwater habitats distributed throughout the island. The lotic habitats comprise a large number of rivers and streams arise from tropical rainforests of the wet zone, particularly from the central hills (i. e. Peak Wilderness) and other montane regions (eg: Knuckles Range) owing to the frequent and high rainfalls and watershed characteristics. The majority of the streams and rivers in the island are perennial, especially those that flow entirely through the wet zone. The flowing-water habitats in the hill-country of Sri Lanka are relatively fast flowing and are aptly named torrential streams (Fernando, 1990). The lentic habitats of the island include man-made lakes, reservoirs as well as natural stagnant water bodies such as forest pools, Inland freshwater marshes, villu grasslands, floodplains and paddy-fields (Arumugam and Ratnatunga, 1974; Thayaparan, 1982). Additionally, coastal and brackish water habitats such as estuaries, lagoons and coastal marshlands are occasionally associated or inhabited by some freshwater ichthyofauna (De Silva and Silva, 1979; Moyle and Cech, 1988).

Each and every kind of freshwater habitats are inhabited by a wide spectrum of freshwater fauna. The total richness of freshwater fish in Sri Lanka consists of 82 indigenous species with 44 are endemic and twenty five introduced species. All these species fell within eight orders and 17 families with Cyprinids accounting for the highest diversity harboring 41 species (Pethiyagoda, 2006). Most of the native fishes are concentrated in the wet zone, which includes the southwestern lowlands and the central highlands. Forested areas of southwestern foothills and the Knuckles Range are exceptionally high in endemism and diversity of freshwater fish (Amarasinghe et al., 2006). The freshwater ecosystems of the wet zone such as streams of tropical rainforests enjoy most favorable limits that promote the optimal physiological, biochemical and behavioral functions of freshwater fish (Senanayake and Moyle, 1984). The Molecular taxonomic research has further strengthened the degree of endemism in Sri Lanka for instance, revealing that some Sri Lankan Puntius species forms a distinct clade with limited biotic exchange with the Indian Puntius species (Bossuyt et al., 2004). 
Despite the surpassing diversity and endemism of Sri Lankan freshwater fish, the research conducted on their ecology, distribution, demography, and genetics is grossly inadequate. Pethiyagoda (1994) conducted an islandwide survey on freshwater fish with reference to their basic biological features. Most of the scientific literature Deraniyagala (1933), Munro (1955), Crusz (1973), Fernando (1990) deals with fish taxonomy. Amarasinghe et al., (2006) review on basic ecological and biological aspects of endemic freshwater fishes of Sri Lanka and emphasize the needs of further in depth ecological studies on Sri Lankan freshwater fishes. Nonetheless, it is imperative to conduct research studies on different aspects of ecology and biology of endangered and endemic species of Sri Lanka, with special reference to promote conservation and even management of these species under critical conditions.

\section{Study Site}

Rawan Oya, a perennial stream, is one of the major water sources of Polgolla Reservoir located in the Kandy district, Central Province of Sri Lanka, which is a distal part of the Victoria - Randenigala - Rantambe reservoir complex. But when becoming urbanized, the anthropogenic activities have lead to altering the aquatic habitat (GEF-SGP, 2006). Majority of the upper watershed area of the stream is covered with undisturbed montane and sub-montane forests of the knuckles Range with a high degree of canopy cover and is covered by clouds during most of the year. Hence, the upper catchments area receives ample amounts of rainfall throughout the year (Wanigasekera and Weerakoon, 1998). The middle part meanders through Pinus plantations, tea plantations, secondary forests and home gardens. Some paddy fields and other agricultural landscapes are common in the vicinity of the lower part of the stream (GEF-SGP, 2003). Angammana area of the stream is mostly covered by typical Kandyan home gardens and secondary forests. The study site varies in altitude from $450 \mathrm{~m}$ (Polgolla Urban Town) to $1500 \mathrm{~m}$ (Hunasgiriya Mountains). Rawan Oya starts from Hunasgiriya Mountain $(1400 \mathrm{~m})$, flows through Angammana, and Wattegama and Polgolla and joins Mahaweli River through Polgolla reservoir at Polgolla, Kandy $(500 \mathrm{~m})$ (Jayeratne, 2005). Rawan Oya is a $13.5 \mathrm{~km}$ long perennial stream; the stream watershed area is $31.07 \mathrm{~km}^{2}$ (longitude $80^{\circ} 39-42$ ' E and Latitude $7^{\circ} 19-23^{\prime}$ $\mathrm{N})$ with a mean annual daily temperature ranging between $22-27^{\circ} \mathrm{C}$ and a mean annual precipitation exceeding $2000 \mathrm{~mm}$ (Figure 1) (GEF-SGP, 2006). 


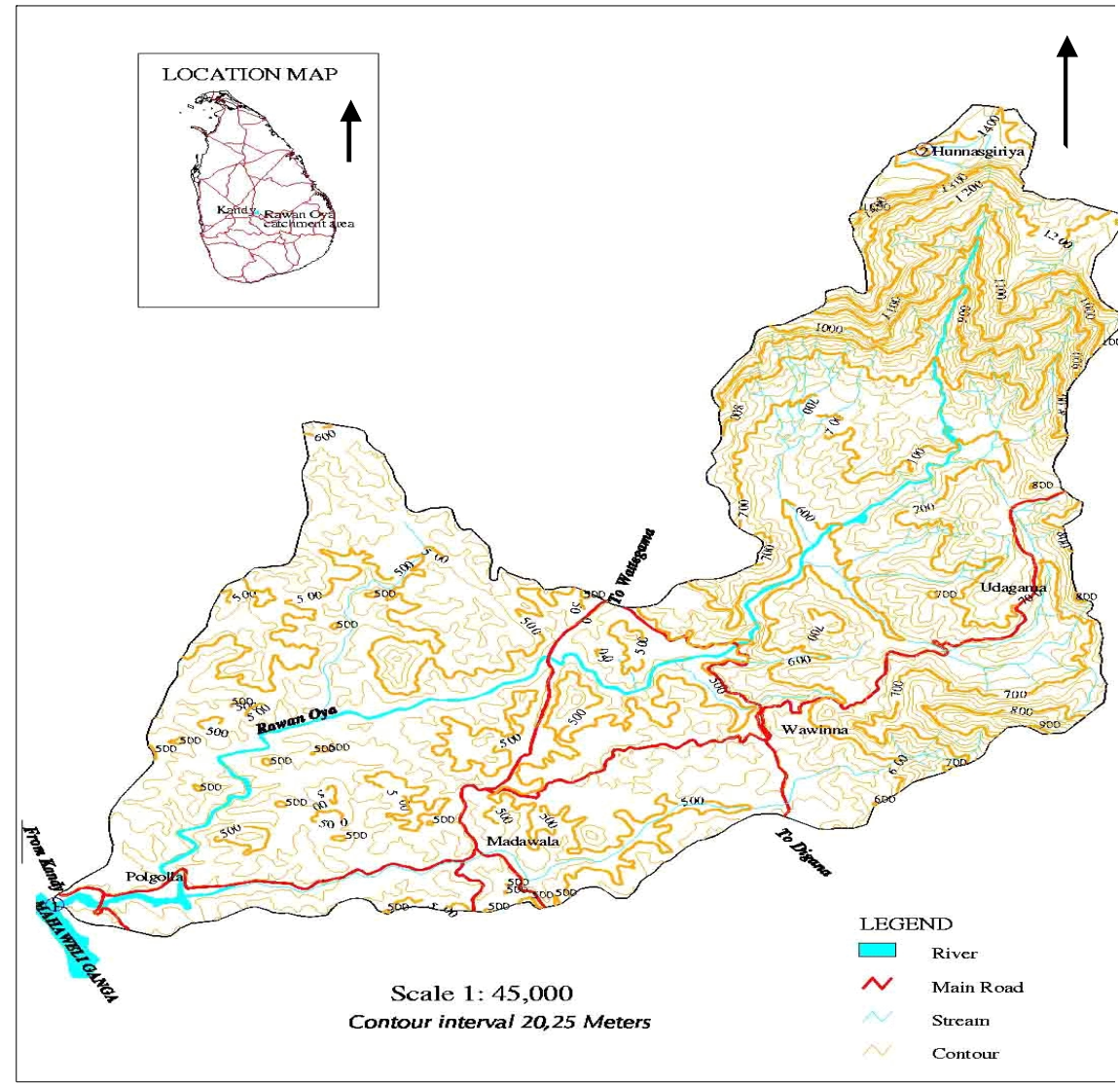

Figure 1: A Geographical map of the Rawan Oya region

Source: Mahaweli Authority (2006)

\section{Objectives}

With the recognition of the importance of ecological studies on the island's freshwater fish we proposed to investigate the freshwater fish diversity and ecology in the main stream of Rawan Oya, a hitherto unstudied left bank tributary of River Mahaweli, the longest river in Sri Lanka.

The specific objectives of this research were:

i. To study the freshwater fish species richness and relative abundance in Rawan Oya

ii. To study the habitat preferences of fish species in Rawan Oya

iii. To study microhabitat selectivity of fish species in Rawan Oya 
iv. To study the freshwater fish's preferred ecological conditions of Rawan Oya

v. To identify the threats to the freshwater fish communities and their habitats

vi. To suggest suitable conservation measures for freshwater fauna and Rawan Oya habitat and immediate terrestrial habitats in association with the stream ecosystem

\section{Materials and Methods}

The study was conducted over a five-month period from May 2005 to September 2005 in headwaters to down stream of Rawan Oya, Kandy, Sri Lanka. Data on species composition and habitat conditions were collected from 30 sampling sites, representing three different lotic habitat types; pools, riffles and runs in the course of streams. Ten locations were randomly selected representing each habitat type. The sampling sites were considered representing different altitudes of the stream $(1100 \mathrm{~m}-500 \mathrm{~m})$. One observation was made representing each sampling site mentioned above. For a particular observation, a 10m-length of the stream was used to get the values for abundance. In each observation, the species encountered and the abundance of each species was recorded and finally the abundance of each species for all ten sampling sites were added and considered as the relative abundance for the entire habitat for a particular habitat type. A five meter gap was left between adjacent sampling locations to prevent re-counting of the same individuals.

The fish were captured using a scoop net $(570 \mathrm{~mm}$ in diameter) and a cast net. For capturing fishes in runs, a 10-meter-length of the stream was blocked using drag nets. The samples were taken between 8.00 am to 12.00 noon. All species were identified according to Pethiyagoda (1991), Munro (1955), Fernando (1990), and Deraniyagala (1952). The numerical abundance of adult fish species was recorded and the fish were released. The presence and absence of the juvenile and larval stages of fish species were noted. In the data analysis, the relative abundance of each fish species were statistically interpreted by Mann-Whitney test through comparing the relative abundance of each species of three the stream habitat types, using MINITAB statistical software release 14.0. Through the Mann-Whitney test, using MINITAB statistical software release 14.0, the significance differences of the fish abundance in the three different habitat types were recognized. Survey through a random sample consisting of 75 people selected from adjacent villages of Rawan Oya. Modifications of the entire stream habitat, human disturbances and other form of threats to the stream habitat and the inhabiting 
biota were also were also recorded from observations. The data on species richness and relative abundance of fish were pooled and the relative abundance of fish species was determined by using Shannon Diversity Index $\left(\mathrm{H}^{\prime}\right)$ and Species richness was determined by using Margalef's Diversity Index (D) (Magurran, 1988).

Important physical and chemical parameters such as the stream velocity, water depth, water temperature, $\mathrm{pH}$, conductivity, dissolved oxygen, biological oxygen demand for a five-day period $\left(\mathrm{BOD}_{5}\right)$ and hardness of the stream water at each pre-selected sampling sites were determined monthly using standard techniques (APHA 1989). These parameters were considered as the microhabitat parameters that signifies the basic ecological conditions in the stream habitats. Hardiness and BOD were determined in the laboratory from the water samples brought from the field. Other parameters were measured in the field. Following is the techniques used in determining the microhabitat features (Table 1).

Table 1: Techniques and instruments used in measuring different microhabitat features in Rawan Oya stream ecosystem

\begin{tabular}{|l|l|}
\hline $\begin{array}{l}\text { Measurement on } \\
\text { microhabitat features }\end{array}$ & Technique/instrument used \\
\hline Stream velocity & Hand held digital flowmeter with flow probe (model: Swoffer 2100) \\
\hline Water depth & Water level meter (model: Watermark 6594) \\
\hline Temperature & Digital thermometer (model: TR Turoni 53201) \\
\hline $\mathrm{pH}$ & $\mathrm{pH}$ meter (model: Jenway MB310) \\
\hline Conductivity & Conductivity meter (model: Jenway 470) \\
\hline Dissolved Oxygen & DO digital meter (model: Jenco 9251N) \\
\hline $\mathrm{BOD}_{5}$ & Wrinkler's titrimetric method \\
\hline Hardness & Titration with0.001MEDTAusing Eriochrome black T as the indicator \\
\hline
\end{tabular}

Results on microhabitat characteristics were subjected to the one-way ANOVA (using MINITAB statistical software release 14.0) to examine the significance of site specific variations of microhabitat parameters in pools, runs and riffles. To determine the most preferred microhabitat parameters (ecological conditions) of freshwater fishes in Rawan Oya, a Pearson Correlation was carried out using MINITAB statistical software release 14.0.

The threats encountered by the freshwater biota, particularly the freshwater fish and the ecosystem in general were assessed by two strategies. 1. Questionnaire survey, involving a random sample of 75 people from adjacent 
villages (Annex 1), 2. Direct observations during field surveys in and around the Rawan Oya.

\section{Results}

A total of 15 fish (Table 2) species belonging to 8 families were recorded of which 2 are endemic while 4 are exotic. Family Cyprinidae had the highest number of species. Figure 2 show the family-wise representation of the fish species recorded at Rawan Oya. Juvenile and larval stages were recorded form the following species; Gara ceylonensis, Schistura notostigma, Puntius filamentosus, Poecilia reticulata, Xiphophorous maculates, Oreochromis mossambicus

Table 2: Species of freshwater fish encountered in the field survey in the selected habitat types of the Rawan, Oya

\begin{tabular}{|c|c|c|}
\hline Family & Scientific Name & Common Name \\
\hline Bagridae & Mystus vittatus & Striped dwarf cat fish \\
\hline Balitoriedae & Schistura notostigma* & Banded mountain loach \\
\hline Cichlidae & Oreochromis mossambicus ${ }^{\#}$ & Mosambique tilapia \\
\hline Cobitiidae & Lepidocephalichthys thermalis & Common loach \\
\hline Cyprinidae & $\begin{array}{l}\text { Rasbo ra danicionius } \\
\text { Devario malabaricus } \\
\text { Tor khudree } \\
\text { Puntius filamentosus } \\
\text { Puntius dorsalis } \\
\text { Puntius bimaculatus } \\
\text { Garra ceylonensis* }\end{array}$ & $\begin{array}{l}\text { Striped rasbora } \\
\text { Giant danio } \\
\text { Mahseer } \\
\text { Filamented barb } \\
\text { Long snouted barb } \\
\text { Red side barb } \\
\text { Stone sucker }\end{array}$ \\
\hline Gobiidae & Glossogobius giuris & Bar-eyed goby \\
\hline Poecilidae & $\begin{array}{l}\text { Poecilia reticulata }^{\#} \\
\text { Xiphophorous maculatus }^{\#}\end{array}$ & $\begin{array}{l}\text { Guppy } \\
\text { Platy }\end{array}$ \\
\hline Loricarïdae & Hypostomus sp & Suckermouth catfish \\
\hline
\end{tabular}

*endemic species \#exotic species 

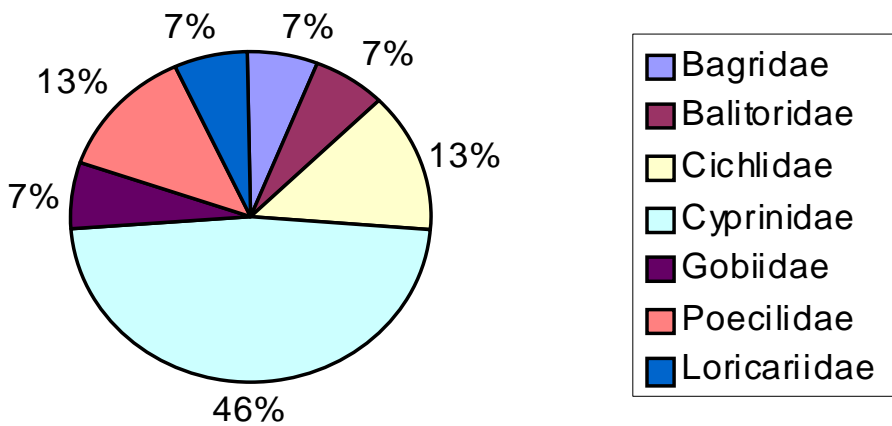

Figure 2: Family-wise representation of species richness of fish in Rawan Oya

The Table 3 summarizes the diversity and abundance of freshwater fish in different habitat types of Rawan Oya. Figure 3 depicts the relative abundance of freshwater fish species in the different habitat types of Rawan Oya. These data revealed that the runs are the lotic habitat that celebrates the highest species richness (12). Riffles are the poorest in species composition (02) whereas the pools housed an intermediate number of species (09).

Table 3: Average values for relative abundance of each fish species in pools, riffles and runs of Rawan Oya

\begin{tabular}{|l|c|c|c|c|}
\hline Fish Species & Pools & Riffles & Runs & Total \\
\hline Hypostomus sp & 5 & 0 & 0 & 5 \\
\hline Devario malabaricus & 0 & 0 & 20 & 20 \\
\hline Garra ceylonen sis & 19 & 30 & 18 & 67 \\
\hline Glossogobius giuris & 0 & 0 & 1 & 1 \\
\hline Lepidocephalichthys thermalis & 0 & 0 & 2 & 2 \\
\hline Mystus vittatus & 0 & 0 & 1 & 1 \\
\hline Oreochromis mossambicus & 4 & 0 & 15 & 19 \\
\hline Puntius filamen tosus & 10 & 0 & 5 & 15 \\
\hline Puntius dorsalis & 5 & 0 & 6 & 11 \\
\hline Puntius bimaculatus & 2 & 0 & 0 & 2 \\
\hline Poecilia reticulata & 10 & 0 & 21 & 31 \\
\hline Rasbora danicoinius & 0 & 0 & 2 & 2 \\
\hline Schistura notostigma & 4 & 10 & 4 & 18 \\
\hline Tor khudree & 1 & 0 & 0 & 1 \\
\hline Xiphophorus maculates & 0 & 0 & 2 & 2 \\
\hline Total Abundance in each habitat type & 61 & 40 & 97 & \\
\hline
\end{tabular}




\section{Pools}
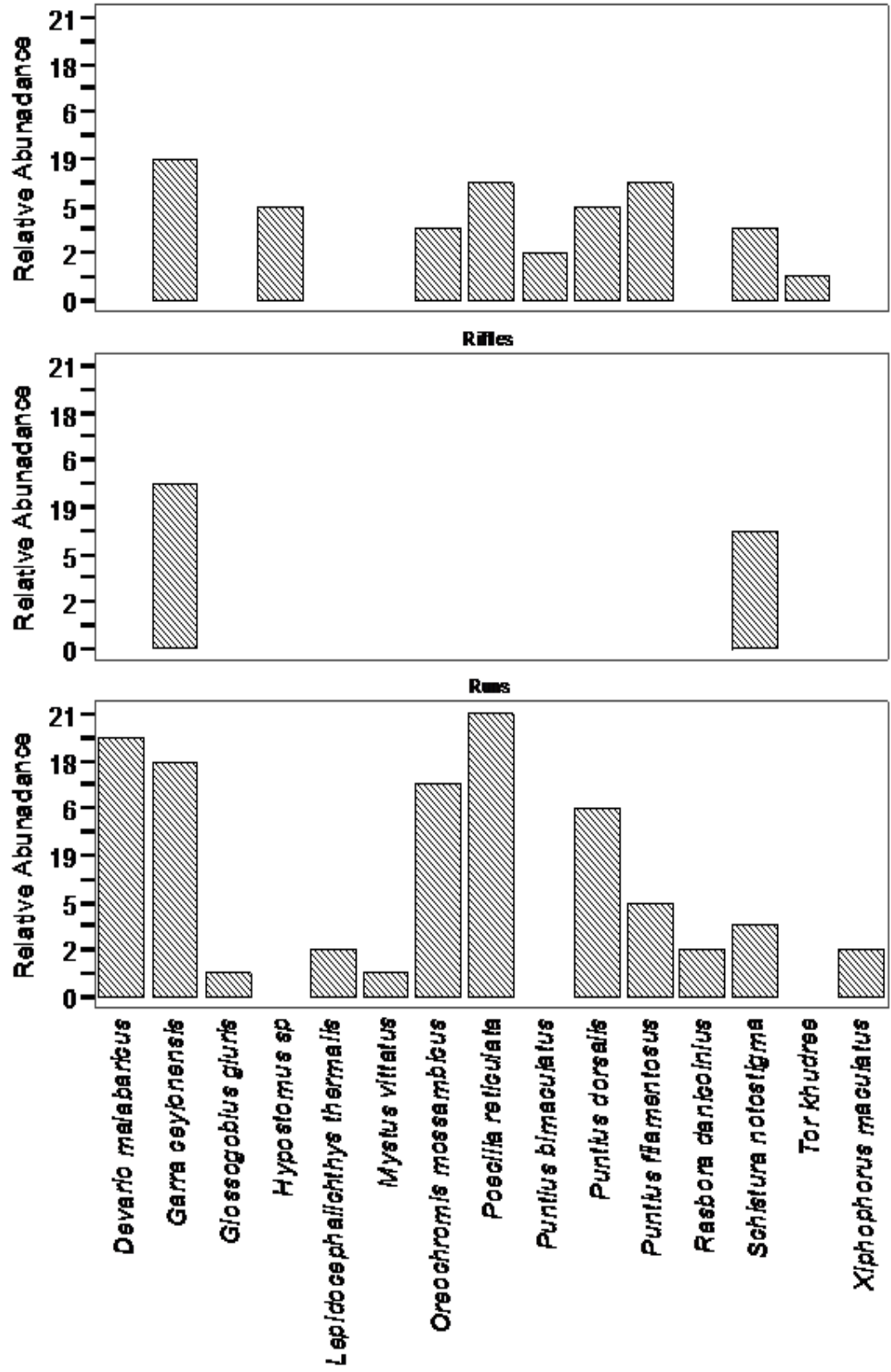

Figure 3: Relative abundance of fish species in different habitat types of Rawan Oya

Table 4 shows that the Shannon-Weiner Diversity Index is highest in runs which justifies the fact that the overall diversity which includes species 
richness and relative abundance is highest in the runs. The Margalef's Index (Table 5) also shows the same trend. Both diversity indexes showed that riffles are the poorest lotic habitat in diversity.

Table 4: Shannon-Weiner Diversity Indices in pools, runs and riffles of Rawan Oya

\begin{tabular}{|l|l|}
\hline Habitat type & Shannon-Weiner Diversity Index \\
\hline Pool & 1.98 \\
\hline Run & 2.17 \\
\hline Riffle & 0.57 \\
\hline
\end{tabular}

$\mathrm{H}^{\prime}=-\mathrm{S} \mathrm{p}_{\mathrm{i}} \ln \mathrm{p}_{\mathrm{i}} \mathrm{H}^{\prime}=$ Shannon Weiner Diversity Index, $\mathrm{P}_{\mathrm{i}}=$ Proportion of $\mathrm{i}^{\text {th }}$ species in the sample

Table 5: Margalef's Diversity Indices in pools, runs and riffles of Rawan Oya

\begin{tabular}{|l|l|}
\hline Habitat types & Margalef's Index \\
\hline Pool & 2.339 \\
\hline Run & 4.288 \\
\hline Riffle & 0.389 \\
\hline
\end{tabular}

$\mathrm{D}=\left(\mathrm{s}^{-1}\right) / \log _{\mathrm{e}} \mathrm{N}, \mathrm{D}=$ Margalef's Index, $\mathrm{S}=$ Number of species found in each habitat, $\mathrm{N}=$ Total number

Looking into the Table 3, it can be concluded that Puntius bimaculatus, Hypostomus $s p$ and Tor khudree are only restricted to pool habitats of the stream. Further, Devario malabaricus, Glossogobius giuris, Lepidocephalichthys thermalis, Mystus vittatus, Rasbora daniconius and Xiphophorus maculatus are confined to runs of the stream. No species seem to be confined to riffles. Garra ceylonensis and Schistura notostigma occupy all three kinds of habitat types. The rest of fish species are occupying both the runs as well as the pools of the stream. The relative abundance of Garra ceylonensis and Schistura notostigma, is significantly higher in riffles than compared with other two habitats (Mann-Whitney Test; w=21.0, $\mathrm{p}<0.05$; for each species). Among the fish that only were recorded form the pools and runs, the abundance of Puntius filamentosus is significantly higher in pools than that of runs (Mann-Whitney Test; $w=57.0, \mathrm{p}<0.05$ ). A reversed conditions is seen in the abundances of Poecilia reticulata and Oreochromis mossambicus where the abundance of runs were significantly higher than that of pools (Mann-Whitney Test; $w=21.0, \mathrm{p}<0.05 ; \mathrm{w}=28.0, \mathrm{p} \mathrm{p}<0.05$ respectively). The abundance of Puntius dorsalis in pools and runs does not significantly differ (Mann-Whitney Test; $w=30.0, p>0.05$ ).

Another interesting finding in this research is the occurrence of Oreochromis mossambicus in high frequencies. Both adults as well as the juveniles were seen in this survey. Further, the nest building behavior and some spawned 
nests were observed in this survey which demonstrates that O. mossambicus is reproducing in this habitat. Being a lake fish (Family: Cichlidae), $O$. mossambicus was so far known to be restricted to lentic habitats (Pethiyagoda, 2006). Hence, this is the first record of O. mossambicus appearing and breeding in running waters, especially in Sri Lanka. Interestingly, alien fish is significantly higher in abundance in the runs than the pools, although the pools resemble their native habitats much closely than runs (Mann-Whitney test; $\mathrm{W}=21.0, \mathrm{p}<0.05$ ). Oreochromis mossambicus seem to prefer runs with direct sunlight exposure and a broader littoral zone that consists of semi aquatic grasses such as Valisneria spiralis.

Table 6 depicts the microhabitat features of the three stream habitat types with the standard deviations and the $\mathrm{F}$ and $\mathrm{P}$ values derived from the ANOVA statistics. The statistical analysis (having zeros for $\mathrm{P}$ values at 95 percent confident level) shows that all the microhabitat parameters significantly differ among the three stream habitat types. Therefore, the differences of diversity and abundances of freshwater fish species in these three habitat types can be attributed to the above mentioned microhabitat parameters. Considering the substrate type of each habitat, there is a muddy substrate with sand in pools, sandy substrate with pebbles in runs and riffles consist of various types of pebbles and big boulders. Table 6 also demonstrates that water temperature, hardness, BOD and conductivity are lowest in the riffles and highest in the pools. Dissolved oxygen concentration and the $\mathrm{pH}$ are highest in the riffles and lowest on the pools. The runs assume an intermediate position with regards to the microhabitat parameters

Table 6: Mean $( \pm \mathrm{SE})$ of the measurements on microhabitat features of water in the runs, pools, and riffles of Rawan Oya and the results of the ANOVA at 95 percent confident level

\begin{tabular}{|c|c|c|c|c|r|}
\hline Parameter & Pool & Run & Riffle & F value & $\begin{array}{r}\text { P } \\
\text { leve }\end{array}$ \\
\hline Water temperature $^{0} \mathrm{C}$ & $22.4 \pm 0.4$ & $21.9 \pm 0.3$ & $20.4 \pm 0.3$ & 47.79 & 0.0 \\
\hline $\mathrm{pH}$ & $7.26 \pm 0.06$ & $6.81 \pm 0.02$ & $7.31 \pm 0.03$ & 232.14 & 0.0 \\
\hline Conductivity $\mu \mathrm{s}^{-1}$ & $259.42 \pm 9.5$ & $220.32 \pm 9.0$ & $34.01 \pm 1.5$ & 1951.88 & 0.0 \\
\hline${\text { Dissolved Oxygen } \mathrm{mgl}^{-1}}^{5} 5.86 \pm 0.07$ & $6.6 \pm 0.06$ & $7.84 \pm 0.06$ & 1240.83 & 0.0 \\
\hline BOD $_{5} \mathrm{mgl}^{-1}$ & $3.7 \pm 0.02$ & $2.9 \pm 0.03$ & $2.0 \pm 0.01$ & 7750.00 & 0.0 \\
\hline Velocity cms $^{-1}$ & $9 \pm 0.7$ & $44 \pm 1.5$ & $63 \pm 1.9$ & 1772.44 & 0.0 \\
\hline Depth cm $^{\text {Hardness } \mathrm{mgl}^{-1}}$ & $180 \pm 11$ & $63 \pm 5$ & $130 \pm 7$ & 265.10 & 0.0 \\
\hline & $160 \pm 8$ & $130 \pm 6$ & $120 \pm 5$ & 52.00 & 0.0 \\
\hline
\end{tabular}

The statistical analysis of the microhabitat parameters with the Pearson correlation (Table 6) revealed some important information about the fish's habitat selectivity. The correlation test revealed that Hypostomus sp, Oreochromis mossambicus, Puntius filamentosus, P. dorsalis, $P$. bimaculatus Poecilia reticulata and Tor khudree are warm water fish that prefer relatively high temperature regimes. In contrast, Garra 
ceylonensis and Schistura notostigma are cold water fish that selects stream microhabitats with relatively low temperature. Further, Devario malabaricus, Glossogobius giuris, Lepidocephalichthys thermalis, Mystus vittatus, Puntius dorsalis, Poecilia reticulata, Rasbora daniconiu and Xiphophorus maculatus prefer slightly acidic water and negatively correlate with increasing pH. Hypostomus sp, Oreochromis mossambicus, Puntius filamentosus, Puntius dorsalis, Puntius bimaculatus, Poecilia reticulata and Tor khudree prefer nutrient rich water where these species demonstrate a positive affinity for conductivity. Further, Devario malabaricus, Glossogobius giuris, Lepidocephalichthys thermalis, Mystus vittatus, Oreochromis mossambicus, Puntius filamentosus, Puntius dorsalis, Puntius bimaculatus, Rasbora daniconius, Schistura notostigma and Tor khudree showed significantly high degree of tolerance to low dissolved oxygen concentration and are used to associate habitats with a high oxygen demand. Only Garra ceylonensis and Schistura notostigma seemed to show a capability to live under high water flow rates where Hypostomus sp, Puntius filamentosus, Puntius dorsalis, Puntius bimaculatus and Tor khudree appeared to prefer relatively still or slow flowing water. The different microhabitat types selected by the 15 fish species recorded at Rawan Oya is listed in Table 7 and Preferred microhabitat types of the freshwater fish species in Rawan Oya (Table 8).

Table 7: Pearson correlation coefficient values shown by each freshwater fish species against each microhabitat parameter measured in the three stream habitat types

\begin{tabular}{|c|c|c|c|c|c|c|c|c|}
\hline \multirow[b]{2}{*}{$\begin{array}{l}\text { Freshwater fish } \\
\text { Species }\end{array}$} & \multicolumn{8}{|c|}{ Pearson correlation coefficient value } \\
\hline & 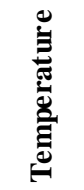 & 蛋 & 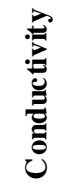 & 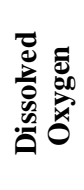 & $\hat{0}_{0}^{n}$ & 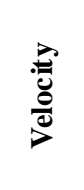 & 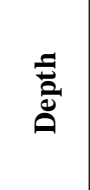 & 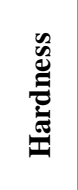 \\
\hline Hypostomus sp & $.693^{*}$ & .419 & $.634 *$ & -.185 & .034 & $-.938^{*}$ & $.821 *$ & $.971 *$ \\
\hline Devario malabaricus & .277 & $-.996 *$ & .353 & $-.844 *$ & $.849 *$ & .169 & $-.905 *$ & -.277 \\
\hline Garra ceylonensis & $-950 *$ & $.636^{*}$ & $-.972 *$ & $.899 *$ & $-.915 *$ & $.719^{*}$ & .158 & $-.637 *$ \\
\hline Glossogobius giuris & .277 & $-.996^{*}$ & .353 & $-.744 *$ & $.849^{*}$ & .169 & $-.905 *$ & -.277 \\
\hline $\begin{array}{l}\text { Lepidocephalichthys } \\
\text { thermalis }\end{array}$ & .277 & $-.996 *$ & .353 & $-.744 *$ & $.849^{*}$ & 169 & $-.905 *$ & -.277 \\
\hline Mystus vittatus & .277 & $-.996^{*}$ & .353 & $-.744^{*}$ & $.849^{*}$ & .169 & $-.905 *$ & -.277 \\
\hline $\begin{array}{l}\text { Oreochromis } \\
\text { mossambicus }\end{array}$ & $.515^{*}$ & $.986^{*}$ & $.582 *$ & $-.894 *$ & $.956^{*}$ & -.091 & $-.765^{*}$ & -.021 \\
\hline Puntius filamentosus & $.961 *$ & -.091 & $.936^{*}$ & $-.990 *$ & $.829 *$ & $-.986^{*}$ & .426 & $.961^{*}$ \\
\hline Puntius dorsalis & $.922 *$ & $-.697 *$ & $.949 *$ & $-.860 *$ & $.945^{*}$ & $-.661^{*}$ & -.238 & $.573^{*}$ \\
\hline Puntius bimaculatus & $.693^{*}$ & .419 & $.634 *$ & $-.785^{*}$ & $.634^{*}$ & $-.938^{*}$ & $-.821 *$ & $.971 *$ \\
\hline Poecilia reticulata & $.701 *$ & $-.919 *$ & $.756^{*}$ & -.298 & .198 & -.321 & $-.593 *$ & .213 \\
\hline Rasbora daniconius & .277 & $-.996^{*}$ & .353 & $-.744 *$ & $.849^{*}$ & .169 & $-.905 *$ & -.277 \\
\hline Schistura notostigma & $-.971^{*}$ & $.577 *$ & $-.987 *$ & $.929 *$ & $-.882 *$ & $.759 *$ & .084 & $-.639 *$ \\
\hline Tor khudree & $.693^{*}$ & .419 & $.634^{*}$ & $.785^{*}$ & $.834^{*}$ & $-.938^{*}$ & $.821 *$ & $.971 *$ \\
\hline $\begin{array}{l}\text { Xiphophorus } \\
\text { maculatus }\end{array}$ & 277 & $-.996 *$ & .353 & -.144 & .049 & .169 & $-.905 *$ & -.277 \\
\hline
\end{tabular}


Table 8: Preferred microhabitat types of the freshwater fish species in Rawan Oya

\begin{tabular}{|c|c|}
\hline $\begin{array}{c}\text { Freshwater fish } \\
\text { Species }\end{array}$ & Preferred microhabitat/s \\
\hline Hypostomus sp & Inhabits many kinds of microhabitats \\
\hline Devario malabaricus & $\begin{array}{l}\text { Clear, slowly flowing water, where both canopy shade and } \\
\text { sunlight-exposure is available with pebbles and boulders }\end{array}$ \\
\hline Garra ceylonensis & $\begin{array}{l}\text { Clear, fast running relatively deep water shaded with a low to } \\
\text { medium height canopy with a algae grown rocky substrate }\end{array}$ \\
\hline Glossogobius giuris & $\begin{array}{l}\text { Slow flowing both clear and turbid water with rock gravel or } \\
\text { sand bottoms }\end{array}$ \\
\hline $\begin{array}{l}\text { Lepidocephalichthys } \\
\text { thermalis }\end{array}$ & $\begin{array}{l}\text { Slow flowing waters with a sandy substrate with decaying } \\
\text { vegetation matter covered by algae }\end{array}$ \\
\hline Mystus vittatus & $\begin{array}{l}\text { Slow flowing waters with some semi-terrestrial vegetation with } \\
\text { a clay mixed muddy substrate }\end{array}$ \\
\hline $\begin{array}{l}\text { Oreochromis } \\
\text { mossambicus }\end{array}$ & $\begin{array}{l}\text { Slow flowing water with direct sunlight expo sure and a good } \\
\text { littoral zone that consists of semi aquatic grasses and a sand } \\
\text { mixed clay containing substrate }\end{array}$ \\
\hline Puntius filamentosus & $\begin{array}{l}\text { Relatively still or slow moving water shaded by a taller canopy } \\
\text { with sunlight penetration through small canopy openings with } \\
\text { good littoral zone which consists of aquatic and semi terrestrial } \\
\text { grasses and roots of larger tall trees }\end{array}$ \\
\hline Puntius dorsalis & $\begin{array}{l}\text { Slow flowing water with direct sunlight exposure and a good } \\
\text { littoral zone that consists of semi aquatic grasses and a sand } \\
\text { mixed clay containing substrate with accumulation of decaying } \\
\text { organic debris }\end{array}$ \\
\hline Puntius bimaculatus & Slow moving or still water with a thick accumulation of detritus \\
\hline Poecilia reticulata & Inhabits many kinds of microhabitats \\
\hline Rasbora daniconius & $\begin{array}{l}\text { Inhabits many kinds of microhabitats } \\
\text { Clear, fast running relatively shallow water exposed to sunlight }\end{array}$ \\
\hline Schistura notostigma & $\begin{array}{l}\text { with no significant canopy cover with a algae grown rocky } \\
\text { substrate }\end{array}$ \\
\hline Tor khudree & Deep water areas of pools with larger boulders \\
\hline $\begin{array}{l}\text { Xiphophorus } \\
\text { maculatus }\end{array}$ & Slow-moving water, silt bottoms and weedy banks \\
\hline
\end{tabular}

\section{Threats encountered by freshwater fish communities of Rawan Oya}

During the research, we followed two procedures to evaluate the threats faced the aquatic biota and the entire ecosystem. We conducted a questionnaire survey through interviewing the general public of the local villages and in addition to that, during the field survey, we were able to make direct observations on human activities that impede upon the biota and the habitat. According to the questionnaire survey, Anguilla nebulosa, Channa gachua and Mastacembelus armatus have previously inhabited the stream, particular in the low and mid elevation regimes but subsequently disappeared from the stream with increased urbanization and human settlements around the stream ecosystem over past 15 years. In the questionnaire survey, 65 percent of residents mentioned that the diversity and the abundance of indigenous fishes in the stream have decreased in general over the past 15 years. 
Several key threat categories were recognized during this research with respect to the stream ecosystem and associated terrestrial habitats of Rawan Oya. They were, i. deforestation of the riverine forest and the upper catchment areas; ii. Excessive application of pesticides and other agrochemicals for the cultivated lands around the stream; iii. Pollution caused by anthropogenic activities; iv. Introduction of exotic fish species to the stream; Extraction of fish for the stream for ornamental and food purposes. Following is a detailed account on the threats prevalent in the concerned ecosystem.

\section{Deforestation of the riverine forest and the upper catchment areas}

Deforestation mainly happens through forest clearing for agricultural purposes in river bunds in the lower part of the stream. The estate based agricultural practices such as small and medium scale tea plantations are recognized as a major factor causing deforestation. Deforestation of the gallery forest and destruction of other forms of riverine vegetation will essentially jeopardize the microhabitat conditions required by the shade loving fish species (Kouadio et al., 2006). For most of the indigenous fish, stable, cool water temperature is required for their metabolism and other biological activities. Logging operation in gallery forests removes the canopy over the stream and destroy the vital microhabitat conditions in the stream (Helfman, 1981).

Further, clearing riverine vegetation will aggravate soil erosion and increase the sedimentation rate in the stream bed, which will on one hand destroy the breeding grounds and foraging niches of benthic fish communities (Hewawasam et al., 2003). Besides, silt and runoff soil particles are known to clog gills of fish and other aquatic fauna and can also reduce the primary production of phytoplankton, algae, mosses and the macrophytes of the stream. Further, if increased sedimentation will reduce the height of water column, especially downstream. Moreover, clearing riparian vegetation at the onset of rain by the tea plantation practice reduces the spawning grounds and nursery grounds of fish (Pethiyagoda, 1994). Apart form that, in and around the functional and abandoned tea plantations, the tributaries of the Rawan Oya have completely dried out. Consider the Polgolla reservoir, which is fed by Rawan Oya, the water capacity is reduced by 40 percent due to siltation (GEF-SGP, 2003). The erosion of riverbanks is common due to deforestation and agricultural practices near the riverbanks of the Rwan Oya (GEF-SGP, 2003).

Although, a Pinus plantation has been afforested by the conservation authorizes covering abandoned tea estates and completely logged areas, the ecological impacts might be further endangering the stream and associated terrestrial ecosystem, such as overextraction of groundwater and subsurface soil water. Besides, the Pinus plantation is not supporting the regeneration of 
the native forest vegetation as expected. Instead, it is proving the ground for invasive scrubs. However, the mitigatory effects of the Pinus plantation are highly questionable. With the absence of strong physical protection and law enforcement by the conservation authorities, deforestation and illicit lumbering operations are happening at alarming rates throughout the terrestrial habitats in the close proximity of Rawan Oya, especially at mid and lower elevations.

\section{Excessive application of pesticides and other agrochemicals for cultivated lands}

Several small scale and medium scale agricultural landscapes are noted in the immediate vicinity of the Rawan Oya. The major type of agriculture in the area is tea where excessive quantities of pesticides and artificial fertilizers are being continuously applied. The nitrate and phosphate containing inorganic fertilizers can get easily washed into the stream with surface runoff since this region experiences heavy continuous rainfall for a longer duration of the year. Such inorganic nutrients will get transported downstream and cause eutrophication when water is relatively stagnant. Nevertheless, unnaturally high nutrient concentrations certainly alter the natural microbial communities that are ecologically important to the stream ecosystem (Biggs, 1997). Use of broad spectrum, persistent pesticides such as organophosphates and carbamates is commonly observed in the area which could impose threats to the stream biota and to the ecosystem in general (Battaglin and Fairchild, 2002). These toxic materials applied to nearby cultivated lands can accumulate in the stream in two potential routes. Primarily, pesticides will accumulate into the stream water with surface runoff. On the other hand, the aerosol pesticides will be carried out by winds towards the stream and may get deposited as dry depositions or may get suspended in precipitation. With time, pesticides may either cause direct toxicity to fish communities resulting instant massive fish kills in future and may become bioconcentrated and biomagnified where multiple physiological and behavioral discrepancies could potentially arise in fish, particularly in those of higher trophic status. (Bermúdez-Saldaña et al., 2005).

\section{Pollution caused by anthropogenic activities}

Many people use Rawan Oya for their daily routine activities such as to washing and bathing. Water pollution is not seen yet observable in the upper area, since the upper elevations of the stream are not having a significant number of human settlements. Nevertheless, in the urban and suburban areas (near major and minor towns) at the lower and middle part of the stream, water pollution is occurring on a large-scale. This is because these areas of the stream are having a higher density of human settlements. Some saw mills and lime industries are built near the stream and such industries 
directly discharge their effluents into the stream. Suspended particles such as saw dust will reduce the light penetration of the stream which intern effect the primary productivity. Presence of chemical wastes will create many short-term as well as long-term adverse impacts on freshwater fauna. The residents were also noted for discarding garbage and kitchen waste, including polythene materials to the stream. Accumulation of higher quantities of solid waste in the stream will even alter the hydrological characters. Pollution by waste disposal damages not only the ecological processes but also the scenic beauty and the aesthetic value of the stream.

\section{Introduction of exotic fish species and invasion by the alien aquatic plants}

Oreochromis mossambicus is the most abundant freshwater exotic fish species encountered in this research. O. mossambicus was released into the Polgolla reservoir and VRR reservoir complex by the government of Sri Lanka during the Mahaweli Development Project as a food fish and also to encourage commercial capture fishery (De Silva, 1988). Today, this species has moved and colonized far from the point of introduction and has successfully established in the stream habitats with continuous perennial breeding. Although Oreochromis mossambicus was only introduced to several reservoirs and lakes to encourage inland fishery and to promote aquaculture as a food fish, this exotic species today have invaded many other lacustrine habitats (Pethiyadoga, 2006). Our observation provide more evidences for this In addition to being an invader of lentic habitats, Oreochromis mossambicus with its observations at a lotic system like Rawan Oya, even including the flowing water regimes. On several previous occasions, this species have been noted in other lotic habitats of the wild, including the streams of protected areas in upcountry (Marambe et al., 2001). As a ravenous plankton feeder and a proliferate breeder who is resilient to a broad ecological conditions, $O$. mossambocus can pose a serious threat with competition for space and food with native freshwater fauna. Oreochromis mossambicus is considered responsible for extinction of Labeo lankae, the endemic carp, who showed an overlapped distribution with that of Oreochromis mossambicus (Pethiyagoda, 2006).

Our inquiries from the local residents and observations revealed that these Hypostomus species are not only accidentally but also purposefully released to the stream by the local inhabitants. It was observed that some local residents release adult fish into the stream when they grow up and achieve a larger body size (it is practically impossible to rear a well grown adult Hypostomus in a tank). Then, in the stream, the fish breed and then the local inhabitants collects back the juveniles from the stream for ornamental purposes. In this way, the stream is used as a rearing and breeding site for 
an alien fish. Hypostomus species are generally known to be predominantly piscivorous even in aquaria and would be certainly outnumbering the native species via predation, especially fry, larval and juvenile stages (Bambaradeniya et al., 1999).

Poecilia reticulata has been introduced to Sri Lanka as a mosquito larvivore fish, in the national Antimalaria Campaign in 1954, by releasing the fish into mosquito breeding grounds urban and suburban canals, ditches and swamps. Secondarily, the fish has also become a tank rearing aquarium fish (Bambaradeniya et al., 1999). Through the questionnaire survey, we learned that Poecilia reticulata has been observed for 5-10 years in the Rawan Oya and associated wetlands, presumably introduced for controlling the Dengue mosquitoes. Perhaps, the fish escaped form the rearing tanks and ponds of local people and colonized the stream too. This species is generally not known to exist or to breed in the wild, and chiefly present in freshwater aquatic habitats of urban and suburban settings. However, previous records show that it is possible to observe these fish in upcountry streams that are in close proximity to human settlements.

Both Xiphophorous maculatus and Hyposthomus have been observed recently, and people have released them to the stream. People believe that there will be no harmful effects by these exotic fish species

Besides the introduced fish, several species of invasive alien aquatic plants were also noted in this research. They were; Eichhornia crassipes, Valisneria spiralis, Pistia and Salvinia molesta. Valisneria spiralis was only found in runs and the rest was only found in the pool habitats. At the point of this research, these plant species were not spreading fast, but if not controlled, might spread throughout the ;length of the stream. These alien species may be harbor or provide vantage for intermediate hosts of parasitic infections for instances freshwater snails and slugs that carry trematode worms that can infect fishes as primary or secondary hosts. Further, these plants absorb huge quantities of dissolved oxygen in water. These plants absorb mineral nutrients from water rapidly in such rates that outcompete the native aquatic macrophytes as well as phytoplankton (Marambe et al., 2001).

\section{Extraction of fish for the stream for ornamental and food purposes}

Through the questionnaire survey, it was discovered that 60 percent of the villagers regularly catch fish for different purposes. Further, it was noted that 55 percent of those who catch fish for food purposes and the rest (15 percent) do it for rearing fish for ornamental purposes in households. It was revealed that the residents of the lower and middle part of the stream catch fish for food, but not on large scale. Oreochromis Mossambicus and T. 
kudree are usually harvested in the middle and lower part. The questionnaire survey revealed that in the past the laborers employed in the tea plantation used to catch G. ceylonensis for food. The local inhabitants showed a significant degree of interest regarding rearing of the ornamental fish form the stream. For instance, $P$. dorsalis is the most popular ornamental species among the villagers, because of its' attractive color patterns which remain unchanged even under captive conditions and the ability to adapt into the small niche spaces such as small-sized glass tanks. The villagers do not collect or breed fish in commercial scale for ornamental or aquarium rearing purposes, but Rasbora daniconius, Puntius bimaculatus, Mystus vittatus, Schistura notostigma, Xiphophorous maculatus, Danio malabaricus and Lepidocephalichthys thermalis are some of the indigenous fishes that were recognized as being used for tank/aquarium rearing purposes in the households in the vicinity of Rawan Oya. However, the local inhabitants do not practice commercial capture fishery form Rawan Oya

\section{Discussion}

The species richness of freshwater fishes of Rawan Oya significantly high where the study site harbors about 18 percent of the islands native freshwater species. The study site falls within the Mahaweli river Basin within which 43 freshwater fish species have been recorded (Pethiyagoda, 1991; Wikramanayaka, 1990a). Interestingly, seven species were recorded considering the elevation regime of our survey (500-1100m) within the entire Mahaweli River Basin. However, later, several Puntius species were introduced to the Mahaweli Basin form Kelani River Basin in the recent past. Nevertheless, the endemicity of freshwater fishes recorded in our research is significantly low. In contrast, ten endemic species occupy the Mahaweli ichthyofaunal province (Pethiyagoda, 1991; Wikramanayaka, 1990b).

Family Cyprinidae is the most species-rich family of freshwater fishes in Rawan Oya. Usually they are the commonest family in stream ecosystems in the wet zone habitats. According to IUCN (2007), there are 17 species belonging to family Cyprinidae (Kullander, 2001; De Silva, 1991). Here only 7 species were found, because Rawan Oya mediates through the mid country and up country wet zone, where the cyprinids are not much prominent. However, most of Cyprinidaes are recorded in typical lowland wet zone habitats, including foothills and the lowland fluviatile, swamps and other lentic habitats (Murray and Little, 2000). High cyprinid diversity has also been recorded form the Keleni river basin and Mahaweli river basin. Further, the number of endemic species recorded at the Ginigathena, an areas falling within the upper part of the Mahaweli basin is higher than that of Rawan Oya (Wickramanayake and Moyle, 1989; Sundarabarathy et al., 2004). 
The significant differences among the measurements of the three stream microhabitat parameters can be attributed to several anthropogenic and natural phenomena. For instances, the water temperature is highest in pools because pools are almost exclusively found in the middle and lower elevation regimes of the main stream. Once the elevation drops, so will the ambient temperature and the water temperature which is in equilibrium with it. Besides, the water flow rate in pools is slow. Therefore the relative stagnant water is exposed to solar heating most of the time with a minimal opportunity for cooling through turbulent flow. The high alkalinity (low $\mathrm{pH}$ Measures) of the pools can be attributed to the human activities taking place in pools such as washing and bathing where large quantities of soaps and detergents are released. Conductivity and hardness of pools and runs seems to be high compared to the riffles. Hardness is the presence of $\mathrm{Mg}^{+2}$ and $\mathrm{Ca}^{+2}$ salts of carbonates in water. Further, soil erosion in the river banks and the upper catchments brings minerals as surface runoff to stream during heavy rains and as they flow downstream, get deposited in pools with their relative stagnancy (Hecnar and M'closkey, 1996).

The temperature is lowest in riffles in Rawan Oya, primarily because all the riffles are in the upper elevations of the stream. Besides, the high water flow rate creates more turbulence which not only decreases the temperature, but also the increases the dissolved oxygen content compared with the other two microhabitats of the stream. The high gradient of topographical elevation and the presence of obstacles in the flow path such as big boulders contribute further towards a faster turbulent flow. The high biological oxygen demand prevalent in pools is partly due to the microbial activities upon relatively high accumulation of degradable organic matter which finally yields aerobic decomposition (Horne, 1994). Pool habitats of a lotic system resemble a lentic system where the biological oxygen demand tends to be high, basically as a result of higher densities of planktonic communities occupying still/slow flowing water compared to fast moving water bodies such as runs and riffles (Wetzel, 2001).

Among the three habitat types concerned, the runs showed the highest species diversity. The prevalence of biologically favorable physico-chemical conditions such as moderate temperatures and moderate water flow rate may be the reason behind this high diversity. The runs of this stream have intermediate characteristics which create suitable conditions which are suited for both running and stagnant water occupants (Horne, 1994). Further, the runs have a varying gradient in terms of depth and presents shallow areas for the growth of macrophytes for species that need aquatic vegetation as an integral part of their niche as well as deep areas for open water species that require a broader water column for their niche (Dumont et al., 1994). Moreover, light penetrates deeper into the bottom in runs and hence supports the rapid 
proliferation of phytoplankton and thence for an increased secondary production of Zooplankton. On the other hand, riffles showed the lowest diversity, which can be attributed to the torrent nature of water flow and the low availability of dissolved nutrient and potentially scarce food supply. Besides, the low height of the water column reduces the spatial scale for a higher diverse biomass. However, pools have much more organic matter accumulation in the bottom than the other two habitats. For a stream ecosystem, the principle energy source comes form the deteriorating organic matter and sustains through allochthonous food chains provides suitable conditions for growth of phytoplankton (Dumont et al., 1994). Consequently the pool habitats potentially account for a higher food availability compared to the other two habitats.

The freshwater fish species found in this research show a significant degree of habitat preference and habitat selectivity based on their ecological adaptability, microhabitat conditions and resource availability in each major habitat type. Generally, the habitat utility of freshwater fish can be explained through the species physiological tolerance, metabolism, food niche and reproductive niche (Dumont et al., 1994). In this study, certain species showed broad ranging among all three major habitat types with higher preference for a particular type, whereas few species seemed to have restrictions in their habitat selection.

Garra Ceylonensis and Schistura notostigma were recorded in significantly higher numbers in riffles of the stream compared to other two habitat types. These two are usually found in shallow, fast flowing water, especially of streams of the central hills at higher elevations (Sundarabarathy et al., 2005; Costa and Fernando, 1967). In our survey, this species was recorded from riffles of upper parts of the stream in high frequencies confirming the above fact. In fact, only G. ceylonensis and S. notostigma occur in the uppermost areas, especially over $1000 \mathrm{~m}$ elevation, where the temperature range is between 18.5 and $19.0^{\circ} \mathrm{C}$ and relatively high dissolved oxygen availability, where the optimal temperature prevails for these species. These two species are well adapted to live in rapidly flowing water with their subterminal suctorial mouth using which the fish attach to the rocks and feed on the algae grown on it (De Silva, 1991; Sundarabarathy et al., 2005). The absence of a preferred substrate may be the reason for these species being low in abundance in pools, which consists of sands and mud at the bottom. Most previous literature regards these species as a prominent fish in the higher hill streams (Silva and Davies, 1986). In contrast to our sampling records and Sundarabarathy et al., (2004) found that G. ceylonensis was the only fish species that dwells on the bedrocks which was the common substratum of the upper region of the Rawan Oya. Our observations disclosed that not only G. ceylonensis and S. notostigma are sympatric but also breed well in 
these habitats. Even within the same major habitat type, these two species demonstrate a habitat partitioning where $G$. ceylonensis prefers canopy shaded, relatively deep waters of the riffles, and on contrast $S$. notostigma selects shallow open water areas of riffles. We noted that these species retain this partitioning even in terms of preferred breeding sites. This kind of habitat segregation prevents competition and allows the maximum diversity to harbor an ecosystem (Macchi et al., 1999).

Mystus vittatus is encountered in very low numbers in this study. This species is much more prominent in lentic waters than in lotic bodies since their food niche consisting aquatic invertebrates such as insects, mollusks and crustaceans that are much more abundant in standing waters (Abbas and Siddiqui, 1984). Hence, low availability of preferred resources may be the reason behind low abundance of this species. Further, this fish apparently selects vantage of moderately vegetated water margins, which is a microhabitat predominant in lakes and swamps rather than streams (Sarkar and Das, 1990).

The four alien fish species are distributed throughout all the major habitat types of Rawan Oya at mid and low elevations. The relatively low water temperature, inadaptability to high water velocity, low dissolved inorganic nutrient content may be preventing the colonization of upper stream by the alien fish species. Both Oreochromis mossambicus and Poecilia reticulata prefers warmer slow flowing water with moderate concentrations of dissolved nutrients (Lowe et al., 2000; Lindholm et al., 2005). The runs that are in the lower part of the Rawan Oya provide good spawning sites for Guppies. O. mossambicus is generally known to be an inhabitant of lentic waters (De Silva et al., 2006). But in our survey, it was revealed that this species in now even invading the natural lotic water bodies too. $O$. mossambicus was only found in the middle portion of the stream, hence most probably, juveniles of $O$. mossambicus, which are released accidentally by pond culture systems near the village Angammana might have initiated and colonized the middle portion of the Rawan Oya. During our survey, we discovered that they breed well in pools, which contain sand mixed muddy substrate with a littoral zone that helps their nest building. Poecilia reticulata was noted for occurring in some polluted runs of the stream, for instance around the urban areas of the Wattegama town, which justifies the fact that it is a hardy fish that can successfully adapt into adverse environmental conditions. $P$. reticulata is generally known to inhabit flowing water bodies of urban and suburban environments, including open drainage canals (Welcomme and Vidthayanon, 2003). Hypostomus sp and X. maculatus, two freshwater species introduced to Sri Lanka for aquarium trade are found only downstream and they have not invaded the middle part of the stream as yet. Xiphophorus maculatus is another exotic fish we recorded I our study 
that is know in be highly resilient and adaptability to a wide physico-chemical environment (Reznick, 1990). This alien fish occurs in warm tropical springs and creeks, open canals and ditches with typically slow-moving water, silt bottoms and weedy banks and swamps. As a benthopelagic fish it feeds on worms, crustaceans, insects and plant matter (Milton and Arthington, 1983).

Lepidocephalichthys thermalis and Rasbora danicionius are common fishes occupying quite running water habitats particularly with a sandy bottom below $600 \mathrm{~m}$ elevation. The low frequency of this species in our research may be the species restriction to lowland habitats (Sundarabarathy et al., 2001; Wikramanayake, 1990b).

The runs in between the upper and middle part of the stream, which consists of big boulders and pebbles, sheltered with the canopy are good spawning sites for Devario malabaricus, which explains the high frequency of this species in the runs. D. malabaricus is a very common fish that prefer boulder strewn mountain torrents rather than lakes and reservoirs although they are generally found in any freshwater habitat in all bioclimatic zones of the country. Nonetheless, in our survey, this species as only recorded form the runs, although they are expected to occur in riffles. The absence of $D$. malabaricus can be attributed to the big boulders that act as barriers and prevent colonization of upper stream from the populations occupying lowelevation regions of the stream (Pethiyagoda, 1991).

Puntius filamentosus adult individuals were mostly found in pools and runs, which are over $2.5 \mathrm{~m}$ deep and possess a significant coverage of aquatic macrophytes. The reason for this type of a habitat selection may be their preference for such habitats for spawning (Axelrod, 1980). The spawning habitats of this species are mostly pools that are rich in organic matter, and muddy substrate, a wider littoral zone with semiaquatic macrophytes with significant shad from the riverine canopy, which consists of big trees such as Terminalia arjuna. These trees provide enough shade and keep water temperature at constant level (Schut et al., 1984). Puntius dorsalis is a common fish in flowing water and in our research were noted form pools and runs, especially in those with a pebble substrate. This observation can be undoubtedly attributed to the feeding habit of $P$. dorsalis as a pebble substrate browser who mainly feed on detritus and benthic diatoms and zoobenthos. Besides, a littoral zone with high density of semi aquatic grasses is required for spawning by this species (Talwar and Jhingran 1991).

P. bimaculatus is an abundant fish even in the hill-streams (Arunachalam et al., 2000). On the contrarily, in our study, we found this species in very low frequencies in pools where there are ample detritus and algal forms are 
relatively abundant. Glossogobius giuris is primarily estuarine that apparently requires brackish or saltwater for breeding. This species has also been recorded form coastal marine environments (Whitfield et al., 1994). Interestingly, this species has bee recorded in many fluviatile and lacustrine lowland inland habitants, especially in dry zone rivers and tanks. The low abundance of this species in our research could possibly be reasoned as the low numbers in the landlocked freshwater populations, particularly towards the central hills (Amarasinghe et al., 1997).

\section{Recommendation of conservation actions for Rawan Oya}

A total of 15 freshwater fishes are present in Rawan Oya, where 2 species are endemic, 12 species have ornamental value and 4 are exotic. Rawan Oya is a diverse aquatic ecosystem. This is one of the major tributaries of Mahaweli River which drains from Hunasgiriya in the Knuckles range harboring a significant number of aquatic fauna. Therefore, protection and management of this invaluable ecosystem is a vital activity. Based on the observations made and the threats prevalent, the following conservation and management actions are highly recommended for the Rawan Oya Ecosystem.

Prevention of deforestation of the riparian forests and the destruction of natural vegetation in the upper catchments of the Rawan Oya.

In order to prevent further degradation of the terrestrial habitats, the upper catchments of the stream should be declared as protected area, preferably as an important hydrological regime of the Knuckles Conservation Area. Currently, the Hunasgiriya forested region is only considered as a proposed reserve (IUCN/FAO, 1997). The physical protection received under this protection status is grossly inadequate and hence ought to be promoted to the status of the forest reserve. With this designation, intense physical protection should be implemented to the Hunasgiriya forests including the catchments, especially to stem the illicit timber felling and encroachments by the tea estate owners. The forest department, as the governmental management authority this ecosystem, should strengthen the physical protection by means of patrolling to detect the illegal human activities such as logging. Along with the designation of the protection status, the boundary of this protected area should be demarcated. In the defining the boundary, it is essential to retrieve the encroached lands as well as abandoned tea plantations into the protected are which can later be subjected to reclamation. The rules and regulations must be tightened and strict amercements should be imposed upon violation of law. Equally, the law enforcement and the legal 
framework on conservation oriented matters should be maintained in a satisfactory level.

Similar conservation measures must be enforced on the riparian vegetation. Riparian vegetation of Rawan Oya is not receiving any conservation status by the government authorities. Hence, it is recommended that a reservation with natural vegetation of suitable extent is allocated for the gallery forest by the forest department for the purpose of prevention of deforestation in the river banks and the immediate terrestrial ecosystem. This reservation should be continuous, throughout the flow of stream, including the urban areas, where the pressure is most intense on the river banks.

Reforestation of deforested and degraded areas of the catchment and the river bank, including the immediate terrestrial habitats of the stream.

A significant, but uncaliberated extent of lands is already deforested and today, is left unused for any propose. Due to the logging practices and forest clearance for tea plantations and other forms of agriculture, some of such lands and river banks are severely degraded. Such barren lands and river banks should be reforested with suitable native fast growing vegetation, which is well adapted to grow in poor soil conditions. A couple of decade ago, the forest department has introduced the Pinus species as a measure to prevent soil erosion in exposed lands (Aston et al., 1987). Such areas should be immediately replanted with native forest vegetation too. In forest replantation, in the initial stages of the vegetation, soil conservation measures should be applied to prevent erosion. Soil conservation measures, such as plantation of grasses, growing hedges, construction of ridges are vital in reforestation actions of the riparian zones. Further, restoration of severely eroded landscapes, such as abandoned tea plantations might have to be subjected to soil enrichment using organic fertilizers and decaying organic matter and other biological soil improvement methods such as plantation of legumes. Reforested lands must be closely monitored until the completion of the primary succession. Such monitoring should ensure that no invasive plant invade the degraded/deforested land. If a previous invasion prevails, before replantation of indigenous forest species, the invasive species must be eradicated manually or mechanically. Introduction of chemical herbicides are not encouraged since such artificial substances may act as a toxicant once on the freshwater biota, especially the aquatic macrophytes and it accumulate in water. 


\section{Introduction of eco-friendly agricultural practices to the inhabit- ants in the vicinity of the stream}

As being described earlier, in the agricultural landscapes, especially in tea plantations, large quantities of agro-chemicals are used. It is highly advised that instead of such synthetic materials, organic farming should be encouraged (Maeder et al., 2002). Herein, it is recommended that natural elements such as compost fertilizers, green manures and insect repelling plant extraction be used as pesticides. Such elements may not cause pollution of stream water. Besides, it is imperative to prevent soil erosion in agricultural lands by applying soil protection measures. Such environmentally friendly agricultural operations will not only preserve the stream ecosystem but also save the cost of maintenance of the agriculture plots (Hole et al., 2005).

\section{Prevention of anthropogenic pollution}

Strong legal actions should be promoted to stop the garbage dumping and releasing waste water from the industries. Serious actions should be ten against the local inhabitants whom dispose waste into the stream and also for industries that discharge wastewater into the stream. Permission should not be granted for establishment of industries that do not adhere to environmental regulations. The regional governmental bodies such as the town councils and divisional councils should carryout a program to remove the solid waste accumulated in the stream. The conservation authority should also empower physical protection to prevent further waste dumping.

\section{Eradication of invasive aquatic species}

Removal of the invasive species form the Rawan Oya should be followed in two steps. First, the sources of introduction should be closed. The four alien fish species recorded in this research colonized the stream in two ways; from the adjacent aquaculture ponds or other culture systems and from upstream migrated fish from Polgolla reservoir, to which these species was introduced for food fishery or other purposes. According to this fact, on one hand, the governmental development schemes should stop releasing alien fishes to the natural and semi natural water bodies, including lakes and reservoirs. Instead, the government can construct culture ponds as a common resource for the fishermen to culture exotic food fish. On the other hand, the culture ponds in the vicinity of Rawan Oya should not discharge the pond water directly to the stream. It is highly advised that the pond water be recycled or reused for other suitable purposes (Clout and Veitch, 2002). Deliberate introduction of introduced fishes to the stream should be completely prohibited. To ensure this, provision of physical protection to the stream ecosystem is a must. The alien species should be manually or mechanically 
harvested. The fishermen can be encouraged to harvest these introduced fish, especially Tilapia by paying them a high price for capturing alien fish species (Clavero and García-Berthou, 2005). Eradication of alien aquatic plants is equally important. In addition to the mechanical and manual removal, even biological controlling methods where a native animal species can be introduced to feed on the invasive species. If an exotic species is to be used as a biological agent, the new species should be experimentally proven to be safe and non invasive in the natural environment. Adverse conditions or aggravations of the prevailing condition should be avoided (Gordon, 1998).

\section{Prevention of extraction of native fish species}

Collection or capturing of fishes form this stream must be limited only to the alien species. Capturing other native species must be prohibited. Such regulations can primarily be achieved through a sound scheme of physical protection with adequate continuous patrolling. Strict penalties ought to be imposed on those who violate rules.

\section{Community based conservation activities including education and awareness programs}

All these conservation approaches will be of a value only if the local communities and the general public are properly acknowledged on the importance of the stream ecosystem and the stream biodiversity. Workshops can be arranged with the participation of the local public and with the involvement of the conservation authority and the regional government. Through such workshops; $i$ the importance of conservation of Rawan Oya ecosystem and its biota must be highlighted, ii the ecological and sustainable ecological benefits of the stream must be emphasized, iii rules and regulations regarding the strict protection of the habitat should be thoroughly explained with references to the penalties on violation, iv the negative effects on the stream ecosystem due to pollution, excessive synthetic agro-chemical use, overextraction of biological aquatic resources, releasing invasive fish, deforestation, encroachments have to be elaborately explained. Moreover, the governmental conservation authorities should involve the local people in conservation actions. For instance, in eradication of invasive species, reforestation programs, the Forest Department can hire the local inhabitants.

\section{Research based activities}

The universities and the governmental agencies in the environmental and natural resources conservation sector of Sri Lanka can involve in research oriented activities. The research should focus long-term evaluation of biodiversity wealth of the stream and the associated terrestrial habitats and 
different conservation and management approaches. Experiments should be done to seek potential for translocation of rare, endangered or endemic species, including fish as well as other aquatic and semi aquatic fauna, even invertebrates. Experimental attempts should also be made to implement invasive species eradication methods through the use of biological agents or biological derivatives. Further, research should also focus on habitat management actions such as to determine the ideal plant species for initiation reforestation programs on deforested and degraded lands. Besides, research activities should also attempt to explore on limnological approaches to increase the stream habitat variation with incorporating more habitat types and ecological niches to increase the species diversity by increasing the natural resource availability and spatial factor, without drastically altering the natural conditions.

\section{References}

Abbas, M.H.S and Siddiqui M.S. (1984) Food and relative abundance of the cat fish Mystus vittatus in a derelict water ecosystem, Indian Journal of Ecology, v.11, pp. 171-173.

Amarasinghe, U.S., Chandrasekara, W.U. and Kithsiri, H.M.P. (1997) Traditional practices for resource sharing in an artisanal fishery of a Sri Lankan estuary. Asian Fisheries Science, v.9, pp. 311-323.

Arunachalam, M., Johnson, J.A., Sathyanarayanappa, S.N., Sankaranarayanan, A. and Soranam, R. (2000) Cultivable and ornamental fishes from Hemavathi and Ekachi rivers, South Karnataka in Endemic fish diversity of Western Ghats. Ponniah AG and Gopalakrishnan A (eds.) National Bureau of Fish Genetic Resources, Lucknow, India.

Arumugam, S. and Ratnatunga, P.U. (1974) Survey of the Island's water resources, springs of Sri Lanka, Water Resource Board, Colombo, Sri Lanka.

Aston, P.S. and Gunathilleke, C.V.S. (1987) New light on the plant geography of Ceylon II, the ecological biogeography, Journal of Biologeography v. 14, pp. 295 - 327.

Axelrod, H.R. (1980) Breeding Aquarium Fishes. T. F. H. Publications, NJ, Unites States.

Bambaradeniya, C.N.B., Ekanayake, S.P. and Gunawardane, J. (1999) Preliminary observations on the status of alien invasive biota in natural ecosystems of Sri Lanka, Report on alien invasive species, GBF-SSEA, Colombo, IUCN Regional biodiversity program, Asia, Colombo, Sri Lanka. 
Biggs, B.J.F. (1997) Eutrophication of streams and rivers: dissolved nutrient-chlorophyll relationships for benthic algae, Journal of the North American Benthological Society, v. 19, pp. 17-31.

Battaglin, W. and Fairchild, J. (2002) Potential toxicity of pesticides measured in midwestern streams to aquatic organisms, Water Science and Technology, v. 45, pp. 95-103.

Bermúdez-Saldañaa, J.M., Escuder-Gilaberta, L., Medina-Hernándeza, M.J., Villanueva-Camañasa, R. and Sagrado, S. (2005) Modelling bioconcentration of pesticides in fish using biopartitioning micellar chromatography, Journal of Chromatography A 1063, pp. 153-160.

Bossuyt, F., Meegaskumbura, M., Beenaerts, N., Gower, D.J., Pethiyagoda, R., Roelants, K., Mannaert, A., Wilkinson, M., Bahir, M.M., Manamendra-Arachchi, K.N.G.P.K.L., Schneider, C.J., Oommen, O.V. and Milinkovitch, M.C. (2004) Local endemism within the western Ghats-Sri Lanka biodiversity hotspot, Science, v. 306, pp. 479-481.

Clavero, M. and Garcý'a-Berthou, E. (2005) Invasive species are a leading cause of animal extinctions. Trends in Ecology and Evolution, pp. 20-110.

Clout, M.N. and Veitch, C.R. (2002) Turning the tide of biological invasion: the potential for eradicating invasive species in Turning the tide: the eradication of invasive species. Veitch CR and Clout MN (eds.) IUCN/ SSC Invasive Species Specialist Group. Gland, Switzerland.

Costa, H.H. and Fernando, E.C.M. (1967) The food and feeding relationships of the common meso and macro fauna in the Maha oya, a small mountainous stream near Peradeniya, Ceylon. Ceylon Journal of Science v. 7, pp. 74-90.

Crusz, H. (1973) Nature conservation in Sri Lanka, Biological Conservation v. 5, pp. 199-208.

Deraniyagala, P.E.P. (1933) Names of some fishes of Ceylon. Ceylon journal of Science, v.5, pp. 79-111.

Deraniyagala, P.E.P. (1952) A colored atlas of some vertebrates from Ceylon: Fishes, National Museum, Colombo, Sri Lanka.

De Silva, S.S. (1988) Reservoirs of Sri Lanka and their fisheries. FAO, Rome, Italy.

De Silva, S.S. and De Silva, E.I.L. (1979) Fish fauna of coastal lagoon in Sri Lanka: distribution and seasonal variation. Bulletin of fisheries Research Station, v.29, pp. 1-9. 
De Silva, K.H.G.M. (1991) Population dynamics and production of the rocky stream-dwelling fish Garra ceylonensis (Cyprinidae) in Sri Lanka. Journal of Tropical Ecology, v.7, pp. 289-303.

De Silva, S.S., Nguyen, T.T.T., Abery, N.W. and Amarasinghe, U.S. (2006) An evaluation of the role and impacts of alien finfish in Asian inland aquaculture, Aquaculture Research, v. 37, pp. 1-17.

Dumont, H.J., Green, J. and Masundire, H. (1994) Studies on the Ecology of Tropical Zooplankton: Developments in Hydrobiology. Springer, Amsterdam, Netherland.

Fernando, C.H. (1990) Zoological survey of Sri Lanka: Freshwater fauna and Fisheries of Sri Lanka. Natural Resources, Energy and Science Authority, Colombo, Sri Lanka.

Global Environmental Facility-Small Grant Program(GEF-SGP) (2003) Towards better conservation of the central hills of Sri Lanka. Environmental News, v. 2, pp.4-5.

GEF-SGP (Global Environmental Facility-Small Grant Program) (2006) Bio diversity conservation and protection of Ravan Oya River banks by Integrated Environment Organization, Online Available: htt:sgp.undp.org/ web/projects/441 biodiversity conservation and protection of ravan oya river banks by integrated environment organiz.html.

Gordon, D.R. (1998) Effects of invasive, non-indigenous plant species on ecosystem processes: lessons from Florida. Ecological Applications v. 8, pp. 975-989.

Gunathilleke, I.A.U.N. and Gunathilleke, C.V.S. (1990) Floristic richness in Sri Lanka, Conservation Biology v. 4, pp. 21-31.

Hecnar, S. and M'closkey, R. (1996) Amphibian species richness and distribution in relation to pond water chemistry in south-western Ontario, Canada, Freshwater Biology v. 36, pp.7-15.

Helfman, G.S. (1981) The advantages to fish hovering in shade. Copeia 1981, pp.392-399.

Hewawasam. T., Von Blanckenburg, F., Schaller, M. and Kubik, P. (2003) Increase of human over natural erosion rates on tropical highlands constrained by cosmogenic nucleotides. Geology v. 31, pp. 597-600.

Hole, D.G., Perkins, A.J., Wilson, J.D., Alexander, I.H., Grice, P.V. and Evans, A.D. (2005) Does organic farming benefit biodiversity? Biological Conservation, v. 122, pp. 113-130. 
Horne, A.J. (1994) Limnology. Charles Remington Goldman, USA.

IUCN/FAO, (International Union for Conservation Nature and Natural Resources / Food and Agriculture Organization) (1997) Designing an optimum protected areas system for Sri Lanka's natural forest conservation, IUCN and FAO, Colombo, Sri Lanka.

Jayeratne, R.L. (2005) Distribution and diversity of freshwater fish in Rawan Oya, Kandy, Sri Lanka, BSc Dissertation. Rajarata University of Sri Lanka, Mihintale, Sri Lanka.

Kouadio, NF., Kouamelan, E.P., Douba, V.N., Kone, T., Snoeck, J. and Ollevier, F. (2006) Updates of fish biodiversity and impact of human activities on the community structure, Me River (Ivory Coast). Journal of Biological Sciences, v. 6, pp. 805-814.

Kullander, F.F. (2001) Phylogeny and species diversity of the South and Southeast Asian cyprinid genus Danio Hamilton (Teleostei, Cyprinidae). Department of Zoology, Stockholm University and Department of Vertebrate Zoology, Swedish Museum of Natural History, Stockholm, Sweden.

Lindholm AK, Breden F, Alexander HJ, Chan W, Thakurta S.G. and Brooks R. (2005) Invasion success and genetic diversity of introduced populations of guppies Poecilia reticulata in Australia. Molecular Ecology v. 14, pp. 3671-3682.

Lowe S, Browne M, Boudjelas S, De Poorter M. (2000) 100 of the World's Worst Invasive Alien Species A selection from the Global Invasive Species Database. The Invasive Species Specialist Group (ISSG) a specialist group of the Species Survival Commission (SSC) of the World Conservation Union (IUCN), Auckland, New Zealand.

Macchi, P., Cussac, V.E., Alonso, M.F. and Denegri, M.E. (1999) Predation relationships between introduced salmonids and the native fish fauna in lakes and reservoirs in northern Patagonia. Ecology of Freshwater Fish. v. 8, pp. 227-236.

Maeder, P., Fliessbach, A., Dubois, D., Gunst, L., Fried, P. and Niggli U. (2002) Soil Fertility and Biodiversity in Organic Farming Science, v. 296, pp. 1694-1697.

Magurran, A.E. (1988) Ecological Diversity and its measurement. Croom Helm London, UK. 
Marambe, B., Bambaradeniya, C., PushpaKumara, D.K. and Pallewatta, N. (2001) Human dimensions of invasive alien species in Sri Lanka in The Great Reshuffling: Human Dimensions of Alien Invasive Species McNeely, JA (eds). IUCN, Gland, Switzerland.

Milton, D.A. and Arthington, A.H. (1983) Reproductive biology of Gambusia affinis (Baird and Girard), Xiphophorus helleri (Gunther) and X. maculates (Heckel) (Pisces: Poeciliidae) in south-eastern Queensland, Australia. Journal of Fish Biology v. 23, pp. 23-41.

Moyle, P.B. and Cech, F.R. (1988) Fish - an introduction to ichthyology. Prentice Hall, Inc, Rugby, UK.

Moyle, P.B. and Senanayake, F.R. (1984) Resource partitioning among fishes in rain forest streams in Sri Lanka. Journal of Zoology London, v. 202, pp.195-223.

Munro, I.S.R. (1955) The marine and freshwater fishes of Ceylon. Dept of External affairs, Canberra, Australia.

Murray, F.J. and Little, D.C. (2000) Inland Fisheries Resources and the Current Status of Aquaculture in Sri Lanka, Working Paper SL1.2 Project R7064, Institute of Aquaculture, University of Stirling, UK.

Myers, N., Mittermeier, R.A., Mitttermeier, C.G., Fonseca, G.A.B. and Kent, J. (2000) Biodiversity hotspots for conservation priorities, Nature v. 403, pp. 853-858.

Pethiyagoda, R. (1991) Freshwater fishes of Sri Lanka. Wildlife Heritage Trust, Colombo, Sri Lanka.

Pethiyagoda, R. (1994) Threats to the indigenous freshwater fishes of Sri Lanka and remarks on their conservation v. 285, pp. 189-201.

Pethiyagoda, R. (2006) Conservation of Sri Lankan Freshwater Fishes in The Fauna of Sri Lanka: status of Taxonomy, conservation and research. Bambaradeniya CNB (eds). IUCN, Colombo, Sri Lanka.

Reznick, D.N. (1990) Plasticity in age and size at maturity in male guppies (Poecilia reticulata): an experimental evaluation of alternative models of development. Journal of evolutionary Biology, v. 3, pp. 185-203.

Sarkar, S.K. and Das, R.N. (1990) Biology of catfish Mystus vittatus and Wallago attu. Environment and Ecology v. 8, pp. 440-443. 
Schut, J., De Silva, S.S. and Kortmulder, K. (1984) Habitat, associations and competition of eight Barbus (Puntitus) species (Pisces, Cyprinidae) indigenous to Sri Lanka, Netherlands Journal of Zoology, v. 34, pp. 459181.

Senanayake, F.R. and Moyle, P.B. (1984) Conservation of Freshwater Fishes of Sri Lanka. Biological Conservation, v. 22, pp. 181-195.

Silva, E.I.L. and Davies, R.W. (1986) Movements of some indigenous riverine fish in Sri Lanka. Hydrobiologia, v. 137, pp. 265-270.

Sundarabarathy, T.V., Edirisinghe, U., Dematawewa, C.M.B. and Nandasena, K.G. (2001) Morphology and some biological aspects of Common spiny or lesser loach (Lepidocephalichthys thermalis) and Banded mountain loach (Schistura notostigma) of Sri Lanka, Tropical Agricultural Research, v. 13, pp. 411-420.

Sundarabarathy, T.V., Edirisinghe, U. and Dematawewa, C.M.B. (2004) Captive breeding and rearing of fry and juveniles of Puntius titteya (Deraniyagala) (Cherry barb), a highly threatened endemic fish in Sri Lanka, Tropical Agricultural Research, v. 16, pp. 137-149.

Sundarabarathy, T.V., Edirisinghe, U. and Dematawewa, C.M.B. (2005) Breeding and larval rearing of threatened, endemic fish stonesucker, Garra ceylonensis (Bleeker). Aquaculture Research v. 36, pp. 196201.

Talwar, P.K. and Jhingran, A.G. (1991) Inland fishes of India and adjacent countries,CRC Press, Rotterdam, Netherland, v. 1.

Thayaparan, K. (1982) The role of seasonal tanks in the development of freshwater fisheries of Sri Lanka, Journal of Inland Fisheries v. 1, pp. 133-167.

Wanigasekera, R. and Weerakoon, S.B. (1998) Study on the bank protection of banks of the Polgolla reservoir against erosion, Proceedings of Institute of Engineers Sri Lanka, 60 ${ }^{\text {th }}$ Annual Session. Central Province Centre, Kandy, Sri Lanka.

Welcomme, R.L. and Vidthayanon, C. (2003) The Impacts of Introductions and Stocking of exotic species in the Mekong Basin and policies for their control. Mekong River Commission (MTC) Technical Paper No. 9, Phnom Penh, Cambodia. 
Whitfield, A.K., Paterson, A.W., Bok, A.H. and Kok, H.M. (1994) A comparison of the ichthyofaunas in two permanently open eastern Cape estuaries. South African Journal of Zoology, v. 29, pp. 175-185.

Wetzel, R.G.. (2001) Limnology: lake and river ecosystems. Elsevier Academy Press, St Louis, USA.

Wikramanayake, E.D. and Moyle, P.B. (1989) Ecological structure of tropical fish assemblage in wet one streams of Sri Lanka, Journal of Zoology London, v. 218, pp. 503-526.

Wikramanayaka, E.D. (1990a) Conservation of endemic rain forest fishes of Sri Lanka: results of a translocation experiment. Conservation Biology v. 4, pp. 32-37.

Wikramanayakc, E.D. (1990b) Ecomorphology and biogeography of a tropical stream fish assemblage, evolution of assemblage structure, Ecology, v. 71, pp. 1756-1764. 